\title{
EDITORIAL
}

\section{Towards knowledge-customer centered services?}

\section{NiLs Timo}

School of Management, Griffith University, Brisbane QLD, Australia

$\mathrm{T}$ his special edition on work and services is timely. Currently, the Australian Parliament House Standing Committee on Economics, Finance and Public Administration is conducting an inquiry in to the current and future directions of Australia's service industries. A distinctive feature of economic change over the past two decades is the exponential growth in services. The Austrade submission to the House of Representatives inquiry suggests that services accounts for $77.9 \%$ of Australia's Gross Domestic Product (GDP), 84.1\% of employment, and 22.8\% of exports (Austrade Submission, August 2006). The growth in services related activities are also significant growing around 3-4\% per annum in Australia (Austrade Submission, August 2006) and around 2-3\% in New Zealand (New Zealand Treasury Economic and Financial Overview, 2002). Government interest in the impact of services on economy has been patchy. The dominance of agricultural and resource industries in Australia has generally shielded greater attention on the role of services in public policy debates. A significant exception was the establishment of the Service Industries Research Program in 1993 (Department of Industry, Technology and Regional Development and the Australian Coalition of Services Industries Inc) that produced a series of interesting commissioned research reports on different slices of the services sector.

The literature on services is vast, and growing constantly in divergent directions. Definitional issues continue to dominate our theorizing of the nature and direction of change and a few trends become noticeable. Historically, and reflecting the strength of technological explanations, early writers such as Bright (1958) and Woodward (1965) saw the machine-product relationship and the characteristics of the overall production process as key elements in understanding technology and work. Emphasis was on the degree of variability of the production processes, plus the type of knowledge-base utilised, that defined different production contexts and characteristics. Industrial sociology was concerned with the impact of automation on working conditions and the working experience (Blauner, 1964) and speculation about future occupational directions (Bell, 1973; Gershuny and Miles, 1983). These early perspectives saw the impact of managerial strategy as benign. However, by the early 1970's, new perspectives began to emerge. First, were the debates sparked by the publication of Braverman's 'Labour and Monopoly Capital' in 1974 that heralded a major debate about long-term trends in work under capitalism, focusing on the role of scientific management in contributing to a deskilling 'dynamic' which redefined managerial control over the labour process (Littler, 1982; Edwards, 1979). From a different vantage point, Levitt (1976) also wrote about the nature of change and the industrialisation of services. Both saw technology as a key strategy for restructuring 
service work by narrowing work tasks, reducing autonomy and discretion. The second wave of research emanated from the debate started by Braverman, that launched a vigorous set of debates about the future of work, which represented the critical labour process perspective focusing on the role of deskilling and managerial control (Braverman, 1974; Friedman, 1977; Edwards, 1979). This research eventually blossomed into a wide ranging critical examination of the capitalist labour process (Littler, 1982; Littler and Salaman, 1982; Littler, 1990; Knights and Willmott, 1990).

A derivation of the second wave was evident in Ritzer's 1993 book 'The McDonaldisation of Society'which attempted to update Braverman's early ideas and redefined Weberian notions of structure and control in the context of a modern consumer society. According to Ritzer, the organisation of contemporary work reflected a series of rationalisation processes that commenced with Taylorism - culminating in the 'McDonaldisation' of contemporary Western work culture. Ritzer argued that scientific management had transformed and 'jumped' from manufacturing to services. The organisation of work and consumer behaviour becomes ritualised in a work system dominated by updated managerial strategies built on rationalisation, replication, standardisation and quantification. Ritzer gleaned support for his contemporary analysis regarding the transformation of work along modern Weberian lines; by emphasising the connection between globalisation, McDonaldisation and the increasing dominance of multinational enterprises corporations (MNC's). Despite criticisms that the 'Braverman approach' was overly deterministic and romanticised the 'aristocracy of labour' (Littler, 1990), the general argument started by Braverman has remained persuasive. A number of other researchers have followed a 'Braverman' path - for example, Hochschild in her 1983 seminal work The Managed Heart: Commercialisation of Human Feeling, and Leidner in her 1993 book 'Fast Food, Fast Talk: Services Work and the Routinisation of Everyday Life' - which located Bravermans' arguments of loss of skill, job fragmentation, work intensification and the degradation of work in a modern context.

By the mid 1980's, the deskilling debate was joined by a third, equally forceful new perspective on trends in work organisation, that was constructed around the notion of 'flexible specialisation'. This perspective was associated with the development of new technologies, the emergence of more discerning markets and new managerial strategies focused on competition and broader business profit strategies (Piore and Sabel, 1984; Streek, 1987). This approach essentially repudiated mass production and Fordist production methods. Instead, new technology, especially information technology was (and still is) seen as fundamentally reshaping the post-industrial workplace (Applebaum and Batt, 1994). This new perspective involved looking at new ways of using labour and incorporating more flexible labour practices into the modern workplace (Atkinson 1985; Allan, 1998). Under this post-industrial paradigm, HR and labour relations practices are seen as increasingly linked to broader business strategies (Kochan, Katz and McKersie, 1986; Schuler and Jackson, 1987). A key feature of this perspective is the role of knowledge - as the post-industrial workplace would become increasingly dominated by a burgeoning knowledge-based labour force. In addition, as cost and competition strategies changed, the traditional demarcation between production and service would become increasingly irrelevant (Pappas and Sheehan, 1998). This approach is essentially an optimistic view of trends in work, however. Despite the optimism, questions regarding managerial control and domination over the labour process remain essentially the same as those first raised in early labour process literature (Hall and Harley, 1995; Harley, 1995). As Russell observes, much of the literature has remained fixed in 'concentrating upon so-called objective features of the workplace while giving short shrift to employee experience in them' (2002: 470); this renders many of our perceptions of workplace change since the 1970's as incomplete. 
Debates continue (albeit at a different speed in labour process-flexible specialisation), while a fourth set of debates has emerged. Originating in the services marketing literature, some researchers consider the characteristics of manufacture and service focusing on: the features of production and consumption; tangible and intangible characteristics; hard and soft aspects of production and service (Gronroos, 1983; Lovelock, 1988). Using this approach, researchers attempted to develop models or taxonomies of manufacture and service as a way of explaining differences and similarities in the manufacture and service task and work organisation (Gershuny and Miles, 1983). Other researchers focused on product characteristics, production processes, customization and service delivery as defining features of the modern work organisation (Silvestro, Fitzgerald and Johnston, 1992; Frenkel, 2000).

The emergence and intersection of services marketing with post Braverman labour process debates has generated considerable theorisation regarding the true nature of shift in technology and work associated with the advent of the internet and powerful information technologies. Much of the research and theorising is drawn from call centres. Some researchers have suggested that call centres represent contemporary examples of the new postindustrial age dominated by powerful forms of information technology and reliant on a knowledge-based labour force. This approach combines essentially the third and fourth perspectives. There is as yet no term that adequately describes this latest approach, but a 'knowledge-customer centered' paradigm comes close. The characteristics of this new perspective can be gleaned from such terms as the 'customer-oriented bureaucracy' (Korczynski, 2002), or the 'mass customised bureaucracy' (Frenkel, et al. 1998) or the 'attenuated bureaucracy' (Frenkel, et al. 1999). These terms suggest fundamental changes in the structure, organisation and skill/knowledge content of the modern service workplace, built upon new forms of consumption (Korczynski, 2005). These perspectives build on debates outside of the labour process regarding changes in competitive strategies (Porter, 1990) and growing attention towards customization (Pine, 1993). The suggestion is that we need a more integrated view of the service workplace; one where more sophisticated HR and employee relations practices are built around team work, the fostering a strong corporate culture, emphasis on professional work, and less overt forms of managerial control (Korczynski, 2002).

\section{CALLS FOR PAPERS}

Journal of Management \& Organization (ISSN 1833 3672) special issues

FAMILY BUSINESS: THEORY \& PRACTICE

Guest edited by Justin Craig, Carole Howorth, Ken Moores and Panikkos Poutziouris Manuscript submission deadline - 20 February 2008

\section{ARTFUL MANAGEMENT EDUCATION \& DEVELOPMENT \\ Guest edited by Cheryl Kerr and Lotte Darsø \\ Manuscript submission deadline - 20 July 2008}

Author Guidelines are available at www.jmanorg.com. Please indicate the title of the special issue and submit to the Editor at JMOEditorial@e-contentmanagement.com eContent Management Pty Ltd, PO Box 1027, Maleny OLD 4552, Australia

Tel.: +61-7-5435-2900; Fax. +61-7-5435-2911 www.e-contentmanagement.com 
However, despite the persuasive nature of the new perspective, and on the question of whether it constitutes a fifth wave, the jury is still out (Fleming et al. 2004). Is the 'new' labour market of services increasingly dominated by growth in knowledge-based workers? As Russell observes, the modern service workplace is complex and 'managerial strategies for inuring a more diverse workforce' to different forms of managerial control is what distinguishes existing service workers from previous generations of industrial workers (Russell, 2002: 487). The result is that research into contemporary service work continues to reevaluate existing assumptions while yielding new insights.

The diversity and complexity of services is illustrated in the choice of papers in this special edition. The paper by Weissenberger-Eibl and Koch trace the definitional issues associated with describing services and propose a useful model of services that incorporates three theoretical dimensions (potential; delivery and process). These dimensions provide a useful focus for understanding and describing service organisations. The importance of gender and emotional labour in the service production - consumption process is discussed in the paper by Luong. The paper highlights the importance of emotion in the service encounter and this is mediated by gender and culture. These are important findings for Australia's culturally diverse workforce. FarrWharton and Brunetto adopt a social exchange perspective to organisational relationships and employee acceptance of change in service SME's. The paper draws on contemporary theory and shows the importance of effective $\mathrm{HR}$ and employee relations' practices in service firms in underpinning change in SME service organisations. The service sector has a high number of SME's and this paper highlights the importance of communication, feedback and employee consultation mechanism to delivering effective workplace change. The growth in and structure of franchising and implications for service HR practices is examined in the paper by Weaven and
Herington. They link the development and success in franchise structures and networks to the implementation of more sophisticated HRM strategies and practices. This has importance for Australia's burgeoning franchising industry. The role of downsizing and restructuring in banking is examined in the paper by Gandolfi. Banking in Australia has undergone significant changes over the past two decades, associated with widespread reductions in the banking workforce. The paper is a comparable study of the strategies adopted by Australian and Swiss banks since the mid 1990's and highlights two separate strategies: Australian banks primarily adopted workforce reduction strategies focusing predominantly on branch closures and labour reduction; whereas Swiss banks implemented more diverse practices associated with organisation redesign, and workplace change. A unique feature of the service workplace is that it plays host to two opposites: it is a place of work for the service workers; it is also a place for social activity; and in some service workplaces, the distinction can become blurred. Hotels are one such service workplace. The paper by Boon deals with the service workplace and space showing that in hotels, space is allocated both on a task and emotion basis. The hotel uniform is one way in which distinctions in task and space are structured. The paper examines the nature of the service encounter in the context of space and illustrates the unique problems associated with the service encounter between front of house and back of house. Staying with hotels, the paper by Knox examines managerial strategy and workplace bargaining choices amongst hotels. The paper illustrates those factors that influence the choice of industrial regulation by hotels and underlines the dilemma faced by hotels: to stay under the award system or to attempt to bargain and implement workplace based regulation (workplace agreement) and the push-pull factors regulating the hotel workplace. The combined effect of these papers is to yield new insights and highlight the rich tapestry that is the modern service workplace. 


\section{References}

Atkinson J (1985) 'Flexibility: Planning for an uncertain future', Manpower, Policy and Practice 1 (Summer): 26-29.

Allan C (1998) 'Stabilising the Non-standard Workforce: Managing Labour Utilisation in Private Hospitals', Labour and Industry 8(3): 61-76.

Appelbaum E and Batt R (1994) The New American Workplace, ILR Press, Ithaca NY.

Austrade (2006) Submission to the House of Representatives Standing Committee on Economics, Finance, and Public Administration Inquiry into Australia's Service Industries, August, Canberra.

Bell D (1973) The Coming of Post-Industrial Society, Basic Books, New York.

Blauner R (1964) Alienation and Freedom, University of Chicago Press, Chicago IL.

Braverman H (1974) Labor and Monopoly Capitalism: The Degradation of Work in the Twentieth Century, Monthly Review Press, New York.

Bright J (1958) Automation and Management, Division of Research, Graduate School of Business Administration, Harvard University, Cambridge MA.

Burawoy M (1979) Manufacturing Consent: Changes in the Labor Process Under Monopoly Capitalism, University of Chicago Press, Chicago IL.

Department of Industry, Technology and Regional Development (1993) Service Industries Research Program, AGPS, Canberra ACT.

Edwards R (1979) Contested Terrain, Heinemann, London.

Fleming P, Harley B and Sewell G (2004) 'A Little Knowledge is a Dangerous Thing: Getting below the Surface of the Growth of 'Knowledge Work' in Australia', Work, Employment and Society 18(4): 725-747.

Frenkel S (2000) 'Introduction: service work and its implications for HRM', International Journal of Human Resource Management 11(3): 469-476.

Frenkel S, Tam M, Korczynski M and Shire K (1998) Beyond Bureaucracy? Work Organisation in Call Centres', International Journal of Human Resource Management 9(2): 957-979.

Frenkel S, Korczynski M, Shire K and Tam M (1999) On the Front Line: Organisation of Work in the Information Economy, ILR Press, Cornell University Press, Ithaca NY.

Friedman A (1977) Industry and Labour,

Macmillan, London.

Gershuny J and Miles I (1983) The New Service Economy: The Transformation of Employment in Industrial Societies, Frances Pinter, London.

Gronross C (1983) Strategic Management and

Marketing in the Service Sector, Marketing

Science Institute, Cambridge MA.

Hall R and Harley B (1995) 'The Australian response to globalisation: domestic labour market policy and the case of enterprise bargaining', in Globalisation and its Impact on the World of Work, Gollan P (Ed.) Australian Centre for Industrial Relations Research and Teaching, ACIRRT Working Paper 38: 71-96, University of Sydney NSW.

Harley B (1995) Labour Flexibility and Workplace Industrial Relations: The Australian Evidence, Australian Centre for Industrial Relations Research and Teaching, ACIRRT Monograph 12, University of Sydney NSW.

Hochschild A (1983) The Managed Heart: Commericalization of Human Feeling, University of California Press, Berkeley CA.

Knights D and Willmott H (Eds) (1990) Labour

Process Theory, Macmillian, London.

Kochan T, Katz H and McKersie R (1986) The Transformation of American Industrial Relations, Basic Books, New York.

Korczynski M (2002) Human Resource Management in Service Work, Palgrave, London.

Korczynski M (2005) 'The Point of Selling: Capitalism, Consumption and Contradictions', Organisation Studies 12(1): 69-88.

Leidner R (1993) Fast Food, Fast Talk: Services Work and the Routinisation of Everyday Life, University of California Press, Berkeley CA.

Levitt T (1976) 'The Industrialisation of Services', Harvard Business Review, Sept- Oct: 63-74.

Littler C (1982) The Development of the Labour Process in Capitalist Societies: A Comparative Study of the Transformation of Work Organisation in Britain, Japan and the USA, Heinemann Educational, London. 
Littler C (1990) 'The Labour Process Debate: A Theoretical Review 1974-1988', in Knights D and Willmott $\mathrm{H}$ (Eds) Labour Process Theory, pp. 46-94. Macmillan, London.

Littler C and Salaman G (1982) 'Bravermania and Beyond: Recent Theories of the Labour Process', Sociology 16(2): 251-269.

Lovelock C (1988) Managing Services: Marketing,

Operations and Human Resources, Prentice Hall,

Englewood Cliffs NJ.

Nankervis A (Ed.) (2005) Managing Services,

Cambridge University Press, Cambridge.

New Zealand Treasury (2002) New Zealand Treasury

Economic and Financial Overview, Auckland, 2002.

Pappas N and Sheehan P (1998) 'The New Manu-

facturing: Linkages between Production and Service Activities', in Working for the Future: Technology and Employment in the Global Knowledge Economy, Sheehan P and Tegart G (Eds), Centre for Strategic Economic Studies, pp. 127-156.

Victoria University Press, Melbourne VIC. Pine B (1993) Mass Customisation: The New Frontier in Business Competition, Harvard Business School Press, Boston MA.
Piore M and Sabel C (1984) The Second Industrial Divide, Basic Books, New York.

Porter M (1990) The Competitive Advantage of Nations, Macmillan, London.

Ritzer G (1993) The McDonaldisation of Society,

Pine Forge Press, Thousand Oaks CA.

Russell B (2002) 'The Talk Shop and Shop Talk:

Employment and Work in a Call Centre', Journal of Industrial Relations 44(4): 467-490.

Schuler R and Jackson S (1987) 'Linking

Competitive Strategies with Human Resource

Management Practices', Academy of Management

Executive 1(3): 207-219.

Silvestro R, Fitzgerald L and Johnston R (1992)

'Towards a classification of service processes', International Journal of Service Industry

Management 3(3): 62-75.

Streek W (1987) 'The Uncertainty of Management and Management of Uncertainty of

Management: Employers, Labour Relations and Industrial Uncertainty in the 1980s', Work, Employment and Society 1(3): 281-308.

Woodward J (1965) Industrial Organisation: Theory and Practice, Oxford University Press, London.

\section{NOW A V A I L A B L \\ HEALTH SOCIOLOGY REVIEW WORKPLACE HEALTH: THE INJURIES OF NEOLIBERALISM

\author{
Edited by Toni Schofield, Faculty of Health Sciences, \\ The University of Sydney
}

ISBN 0-9750436-4-1; iv + 92 pages; softcover

A special issue of Health Sociology Review (August 2005)

Neoliberal policy is characterised by the retreat of business and governments from ensuring that workplaces do not kill or maim workers. Injury management schemes now also fail to recognise injured workers as citizens with rights to dignified, compassionate and appropriate treatment.

This book identifies strategies to address the injurious effects of neo-liberal governance and management through collective industrial and political action.

Contents, Abstracts, Editorials, Articles and Order Form at: http://hsr.e-contentmanagement.com/14.1/

Course Coordinators are invited to contact the Publisher for an adoption evaluation copy. 